\title{
IAMJ
}

INTERNATIONAL

AYURVEDIC

MEDICAL JOURNAL

Review Article

ISSN: 23205091

Impact Factor: 5.34

\section{ROLE OF JALAUKAVCHARAN IN ADHIMANTHA WITH SPECIAL REFERENCE TO GLAUCOMA}

\author{
Govind D Tundalwar ${ }^{1}$, Komal K Sharma ${ }^{2}$, Nitin A Vyawhare ${ }^{3}$, Jayshree J Malwe ${ }^{4}$ \\ ${ }^{1}$ Associate Professor, ${ }^{2,3,4} \mathrm{PG}$ Scholar, \\ Department of Shalakyatantra Dept. Shri Ayurved Mahavidyalaya, Nagpur, Maharashtra, India
}

Corresponding Author: drgovind2005@gmail.com

\section{https://doi.org/10.46607/iamj2308092020}

(Published online: September 2020)

Open Access

(C) International Ayurvedic Medical Journal, India 2020

Article Received:06/08/2020 - Peer Reviewed:14/09/2020 - Accepted for Publication:12/09/2020

Check for updates

\begin{abstract}
Raktamokshana is the procedure of Panchakarma. Jalaukavcharana is the type of Raktamokshana. A detail description on Jalaukavcharan is available in Ayurveda. It is used in the management of various diseases in all the systems of the body including ears, nose, throat, eyes and head. Now a day Leeches are also used by ophthalmologists to treat inflammatory, traumatic processes and various diseases of eyes. There are various bioactive substances are present in saliva of leech. Along with that, it also exerts a therapeutic effect in several diseases. $J a-$ laukavcharana is very effective ancient method of Panchakarma neglected by physician. There are many side effects of modern medicine. So, it is the need to spread awareness about Jalaukavcharana and its efficacy. Thus, Jalaukavcharana is the alternative therapy promising more effective and safer outcome for the society.
\end{abstract}

Keywords: Jalaukavcharana, Raktamokshan, Adhimanth, Glaucoma.

\section{INTRODUCTION}

Adhimanth has been contributed to negligence or improper management of Abhishyanda both from diagnostic as well as treatment point of view ${ }^{1}$. Further the disease Adhimantha presents the features that are similar to those of glaucoma in modern science. The present trend of treating glaucoma is hypotensive medical treatment, meiotic therapy, carbonic anhydrase inhibitors and osmotic agents ${ }^{2}$. In most cases this treatment is followed by surgical treatment. In spite of all these treatment modalities, these have very 
little effects while surgery is not out of danger. Considering these facts, the present study was undertaken to find out its solution for management of glaucoma.

The word leech is derived from 'laece' which means physician. Leeches are given the name of Jalauka because of their site of dwelling and the source of their nutrition is $j a l a^{3}$. It was used to treat a wide range of ophthalmic diseases, becoming a standard treatment for almost every ailment. It was practiced prophylactically as well as therapeutically. In Ayurveda, bloodletting therapies through leech are used in management of various disorders, especially which are caused due to vitiation of Pitta and Rakta Dosha.

\section{Aim and Objectives:}

1. To reveal the role of Jalaukavcharana in Glaucoma disease.

2. To do analytical study of Jalaukavcharana in Netraroga mentioned in Ayurveda.

Material and Methods: The data was collected from Ayurveda textbooks, Vaidyas and through personal experiences.

Types of Leeches: In Shushrutasamhita, 12 types of leeches are found and classify them into 2 main categories i.e. Savishajalauka (poisonous) and Nirvishajalauka (non-poisonous) ${ }^{4}$

$\begin{array}{ll}\text { Savishjalauka } & \text { NirvishJalauka } \\ \text { 1 Krushna } & \text { 1 Kapila } \\ \text { 2 Karbura } & \text { 2 Pingala } \\ \text { 3 Alagarda } & \text { 3 Shankhamukhi } \\ \text { 4 Indrayudha } & \text { 4 Mushika } \\ \text { 5 Samudrika } & 5 \text { Pundarikamukhi } \\ \text { 6 Gochandana } & \text { 6 Savarika }\end{array}$

Contraindications of leech applications ${ }^{\mathbf{5}}$ : According to Ayurveda, leech application should not be performed in a patient suffering from Sarwangashopha, Kshina, Shosha, Pandu, Udara and also Garbhini.
Selection of Jalauka: Out of twelve, only six varieties of nonpoisonous leeches are used for medicinal purpose. Shankhamukhi type of leech is preferably used for medicinal purpose due to its rapid blood sucking capacity. As per classical description of Ayurveda, the leech neither too long nor too small should be preferred for therapeutic purpose ${ }^{6}$.

Storage and Maintenance: The leech will survive quite happily in a cool place provided the temperature. Does not exceed 15-20 leech should be stored in a well labeled container having multiple pores on the top for proper aeration. Avoid direct exposure to sunlight to the leeches. The water of container should be chlorinated and should be replaced after 5 to 6 days. About 50 leeches can be kept in one gallon (4 liter) of water, for best result, we should keep two leeches/ 250 $\mathrm{ml}$ of water. If it is not possible to get the chlorinated water, then keep the container of water in the open air for a period of time and then use it for storage of leech. It is better to avoid direct exposure of sunlight to the leeches.

\section{Method of Jalauka application:}

\section{Purvakarma:}

1. Proper Snehan (oleation) and Swedana (sudation) of the patient.

2. Purification of leech by pouring the leech in water mixed with turmeric powder.

3. Part preparation- Cleaning of part of the body to which leech is going to be applied.

Pradhankarma: Before application, prick the skin with a sharp and sterile needle so that drop of blood comes out then applied the leech through its front end and covers the leech by wet cotton. If the leech is not ready to suck the blood from body part then application of Madhu, Ghruta or butter should be done. 


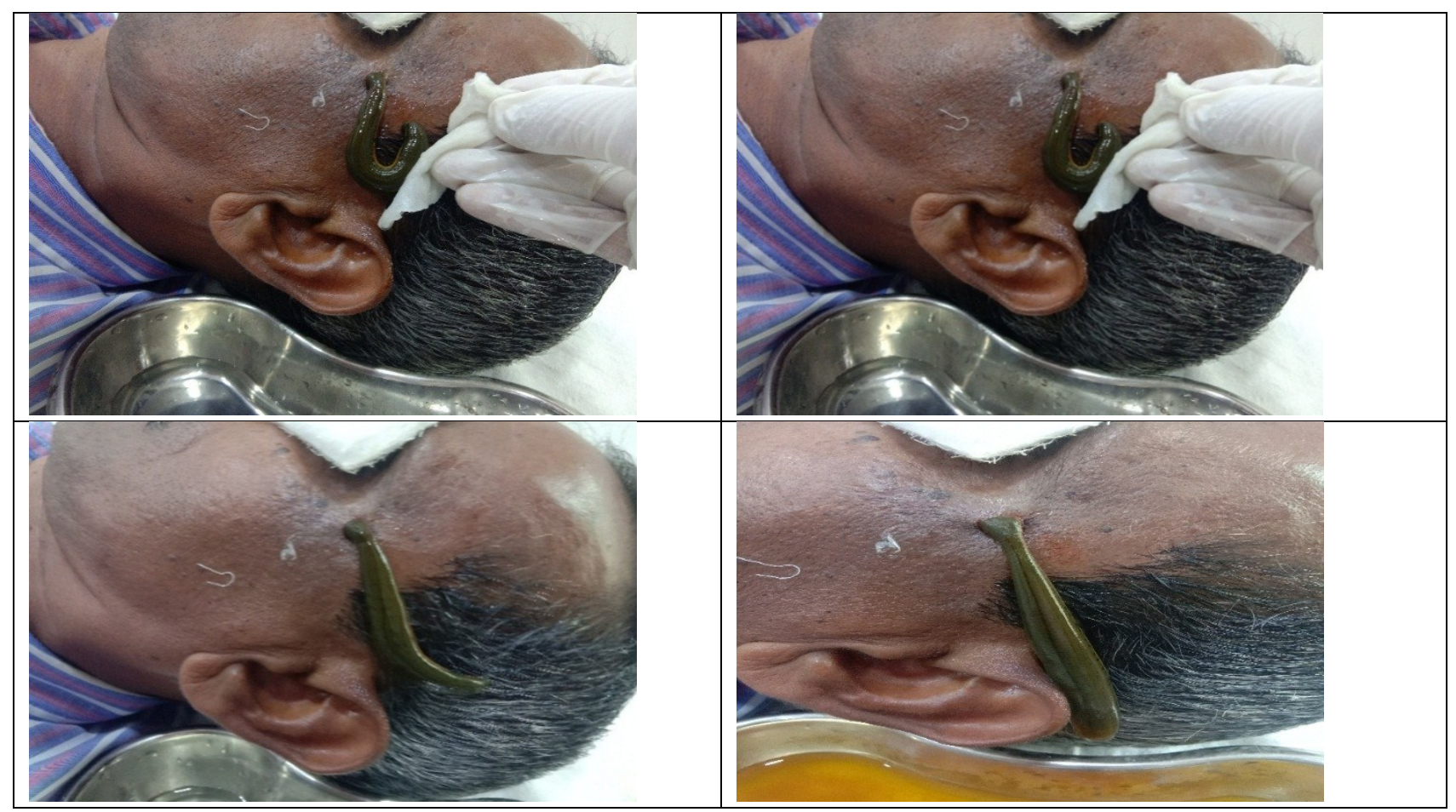

\section{Observation of leech during blood sucking:}

While sucking the blood following signs appears in the body of leech.

1. Gradual distention in the central portion of the body of leech.

2. Itching and burning sensation at the site of bite.

3. Pulsations on the body of leech may be visible.

Removal of leech: After 30-70 minutes the leech is removed by itself, or by application of turmeric powder on the mouth of leech.

\section{Paschatakarma:}

Care of wound- After detachment of leech, there is triangular wound created by the mouth of leech. The blood comes out from the wound. The bleeding from the wound is checked by application of tight bandaging with the use of Yashtimadhu or turmeric powder.

Emesis of sucked blood- induction of emesis the leech that is applied to the lesion undergoes a process of Vamana so that the same leech can be applied next time to the same patient. For the Vamana of leech, turmeric powder is applied over the mouth of leech.

\section{Precaution during leech application:}

1. Bleeding and clotting time of the patient should be normal.

2. Gentle handling of leech.
3. Cover the leech with wet cotton.

Adverse effect of leech therapy: The leech therapy is very safe procedure, however some adverse effects reported by scientists these are local pain, itching, hypotension, vasovagal attack, hemorrhage, infection, allergic reactions, ulcerative necrosis and transmission of infectious diseases. ${ }^{7-11}$

Frequency of leech application: The frequency of leech application will vary according to disease and severity. Generally, leech should be applied once a week up to six sittings. One leech should be reserved for a particular patient to avoid cross infection.

Netrarogsamprapti ${ }^{\mathbf{1 2}}$ : Prakupit Tridoshas vitiated by Hetusevan goes through Urdwagami Sira of Netra and produces Daruna Netraroga. Netra is the site of Alochaka Pitta. The properties of Pitta and Rakta are same as they have Aashrayasrayibhav. In such condition, Jalaukavacharana is very useful in Netraroga produced by Rakttadushti and Pittadushti. So, Raktamokshana is useful in following Netrarogas:

Abhishyanda (conjunctivitis), Adhimantha (glaucoma), Siraharsha (inflammation), Sirotpata (hyperemia), Puyalasa (dcrocystitis), Vatparyay (ocular pain), Sashophaakshipaka (purulent conjunctivitis), Ashophaakshipaka (conjunctivitis). 
Glaucoma: Glaucoma is not a single disease. It has multi factorial etiology and characterized by progressive optic neuropathy resulting in a characteristic appearance of optic disc and a specific pattern of irreversible visual field defect that are associated frequently but not invariable with raised intraocular pressure ${ }^{13}$. Eye contains fluid called aqueous humor that continuously circulates in and out of eye. Aqueous humor is produced by ciliary process of ciliary body. Whenever there is block in drainage process intraocular pressure increases causing damage to optic nerve ${ }^{14}$. Leech therapy facilitates drainage of aqueous humor through the trabecular meshwork. As the leech suck peripheral blood, it creates negative pressure in the vein present locally and facilitates drainage. A number of setting may be required depending upon the improvement of patient.

Hirudin also help in reducing the blood thickness, thereby promoting optimum blood flow and preventing the risks associated with sluggish blood flow ${ }^{15}$. The patient who suffers from pain and inflammation will feel relief from the anti-inflammatory and anesthetic effects of the leech's saliva.

\section{DISCUSSION}

Adhimantha has drawn attention of ancient physician which is evident from the fact that its description, classification, symptomatology, complication and management are available in literature. Even though the disease Adhimantha has been considered as a curable disease if the treatment is given well in time otherwise the disease results in further deterioration and ultimately blindness ensues. Jalaukavcharana is one of the very effective treatment modalities for treating various Netrarogas as well as in many systemic diseases. When a leech is applied to biological active areas of human body, the bite itself gives a positive effect.

\section{CONCLUSION}

The scientific explanation of the disease along with its symptomatology has brought out the fact that the disease Adhimantha has similarity with glaucoma in its clinical presentation. It is one of the clinically defined conditions of the eye where in at least more than two symptoms need to be looked for. The clinical presentation of disease is based on symptoms like blurring of vision, pain in the eye, headache, raised intraocular pressure, optic disc cupping and visual field changes. According to modern science, leech's saliva contains Hirudin Hyaluronidase enzyme which acts as anticoagulant, local anesthesia, anti-inflammatory, vasodilator, antithrombotic, hypotensive and analgesic effect. Hence, more efforts should be undertaken to optimize this utilization. More clinical trials are required to assess leech efficacy and safety in the treatment of eyes.

\section{REFERENCES}

1. Sushrutasamhita, Ambika Datta Shastri, $12^{\text {th }}$ edition, 2001, Chaukhambha Orientalia, Gopal Mandir Lane, Varanasi.

2. Ashtang Haridaya, Prof. K.R. Srikantha Murthy, Reprint 2002, Krishnadas Academy, Varanasi.

3. Sushruta Samhita, Ambika Datta Shastri; Part 1, Sutrasthana, Jalaukavcharaniya Adhyaya 13/9, Edition Reprint 2005, Chaukhambha Prakashan, Varanasi.

4. Sarth Vagbhata by Ganesh Krushna Garade, Chaukhambha Surbharti Prakashana Varanasi, Edition Reprint 2014, Sutrasthana chap. 26/29, pp-102.

5. Sushruta Samhita, Ambika DattaShastri; Part 1, Sutrasthana, Jalaukavcharaniya Adhyaya 14/24, Edition Reprint 2005, Chaukhambha Prakashan, Varanasi.

6. SushrutaSamhita, Ambika Datta Shastri; Part 1, Sutrasthana, Jalaukavcharaniya Adhyaya 13/18, Edition Reprint 2005, Chaukhambha Prakashan, Varanasi.

7. Mateos Micas M, Garcia Diez E, Forteza Gonzalez G. Sanguijuelasmedicinalis: utilidaden microcirugia. Proposito de uncaso. Rev Esp Cir Oral Maxilofac. 2001;23:90-94

8. Yantis MA, O'Toole KN, Ring P. Leech therapy. Am J Nurs 2009; 109:36-42; quiz 43

9. Kalbermatten DF, Rieger UM, Uike K, et al. Infection with Aeromonashydrophila after use of leeches in a free microvascularosteo-(myo)-cutaneous flap- suggestions for successful management. Handchir Mikrochir Plast Chir. 2007; 39:108-111

10. Altamura D, Calonje E, Liau JI, Rogers M, Verdolini $\mathrm{R}$, Diffuse cutaneous pseudolymphoma due to therapy with medicinal leeches JAMA Dermatol. 2014;150: $783-4$ 
11. Khelifa E, Kaya G, Laffitte E, Cutaneous pseudolymphomas after leech therapy J. Dermatol. 2013; 40: 6745

12. Sushruta Samhita, Uttartantra by Hemanta Panigrahi, Vol-1, Chaukhambha Orientalia, First Edition 2005, Chapter 1/20, pp-15

13. Comprehensive Ophthalmology by A.K Khurana, New age international publication, $4^{\text {th }}$ edition 2007 chap-9, pp-210,211

14. Clinical Ophthalmology by Jack J Kanski, $5^{\text {th }}$ international edition, Butterworth Heinemann publication New York 2003, chap no-8, pp-170.

15. Review of leech application in Ayurveda and Shrilankan traditional medicine, by E.R.H.S.S. Ediriveera, article published in JAHM, Volume $\|$, Issue |, pp 62-76

\section{Source of Support: Nil \\ Conflict of Interest: None Declared}

How to cite this URL: Govind D Tundalwar et al: Role Of Jalaukavcharan In Adhimantha With Special Reference To Glaucoma . International Ayurvedic Medical Journal \{online\} 2020 \{cited September, 2020\} Available from: http://www.iamj.in/posts/images/upload/4447_4451.pdf 